\title{
ENVIRONMENTAL RISK FACTORS FOR CANINE TOXOPLASMOSIS IN A DEPRIVED DISTRICT OF BOTUCATU, SP, BRAZIL
}

\author{
CAMOSSI LG (1), FACCIOLI PY (1), MENOZZI BD (1), DAHER SR (2), \\ LANGONI H (1)
}

(1) Department of Veterinary Hygiene and Public Health, Veterinary Medicine and Animal Husbandry School, São Paulo State University, UNESP, Botucatu, São Paulo State, Brazil; (2) Department of Pediatrics, Botucatu Medical School, São Paulo State University, UNESP, Botucatu, São Paulo State, Brazil.

ABSTRACT: Toxoplasmosis is a worldwide zoonosis caused by Toxoplasma gondii that can infect a large variety of animals, including humans. The present study aimed to evaluate the frequency of anti-T.gondii antibodies in dogs from a peripheral district of Botucatu and to establish the association among some epidemiological variables in order to evaluate risk factors for toxoplasmosis infection. Serum samples from dogs were screened using an indirect fluorescent antibody (IFA) test. Anti-T.gondii antibody prevalence was $56 \%$. The highest titer was $1024(1.79 \%)$ and the most frequent titers were $16(57.14 \%)$ and 64 (33.93\%). The chi-square $\left(X^{2}\right)$ test revealed significant association among variables such as dog access to street, ingestion of raw meat and presence of synantropic animals in the domestic environment. These results demonstrate that toxoplasmosis is present in dogs from Jardim Santa Elisa district.

KEY WORDS: Toxoplasma gondii, dogs, IFA, risk factors.

CONFLICTS OF INTEREST: There is no conflict.

\section{CORRESPONDENCE TO:}

LUCILENE GRANUZZIO CAMOSSI, Departamento de Higiene Veterinária e Saúde Pública, Faculdade de Medicina Veterinária e Zootecnia, Universidade Estadual Paulista, UNESP, Distrito de Rubião Júnior, s/n, 18618-000, Botucatu, SP, Brasil. Email: camossi@fmvz.unesp.br. 


\section{INTRODUCTION}

For its medical and veterinary importance, the Toxoplasma gondii has been the most intensely studied parasite among the coccidia, including aspects about its biology, biological cycle, epidemiology and pathology. It is an obligatory intracellular protozoan, with complex vital cycle involving felines as definitive hosts and a large number of intermediate hosts such as warm-blooded animals, including man.

This infection has already been registered in approximately 300 mammal species (carnivores, herbivores, insectivores, rodents and primates) and 30 bird species. Due to the wide distribution of the T. gondii in nature, Jacobs, in 1957, affirmed that humans live in a sea of toxoplasmic infection (11). In fact toxoplasmosis is widely distributed. It is believed that a third of the world's human population is infected, consisting a global concern due to the increase of its occurrence and strong association with acquired immune deficiency syndrome (AIDS).

In T. gondii's complex life cycle there are three infection stages: the tachyzoites that multiply quickly; the bradyzoites that multiply slowly and are usually found in the tissue cysts; and the esporozoites, found in oocysts. While the tachyzoites and bradyzoites occur in tissue of all infected animals, oocysts are only excreted in the feline feces (10), a situation partially responsible for environmental contamination, contributing extensively to the agent's great dissemination in nature.

T. gondii can be transmitted in several manners, principally transplancentally by the tachyzoite passage; by the ingestion of food or water contaminated with sporulated oocysts eliminated by the feline feces and by the ingestion of raw or undercooked meat containing tissue cysts (13). The transmission can also happen by tachyzoites contained in blood products, by organs transplants or by unpasteurized milk (24), mainly from goats.

Although T. gondii does not develop its enteroepithelial cycle in dogs, who are not consumed as food in most developed countries, several studies highlight their importance in the epidemiological chain of the disease, due to direct contact between humans and these animals. A risk factor to be considered is the one provoked by xenosmophilia, the habit in which they eat or roll in cat feces, because dogs may carry $T$. gondii sporulated oocysts in the fur, transmitting the infection to man (15). It is undisputed that the risk of transmission to humans, in this case, is much lower. However, this risk factor should not be ignored in the epidemiological chain of toxoplasmosis transmission to humans. 
Besides this aspect, dogs can also play a role as mechanical vectors. When these animals ingest the sporulated oocysts, they can eliminate the infective form into the environment by feces, generating one more source of infection for humans. Either through coprophagia or xenosmophilia, dogs can contaminate the domestic environment, affecting humans as well as other susceptible animals (15).

Vegetables and animal products infected with oocysts, primarily swine and ovine derivatives containing cysts with bradyzoites, are most responsible for human infection. Besides food, polluted soil and infected rodents are also involved, as a consequence of dog carnivorous behavior (2).

Dogs are utilized to accomplish serological surveys with the purpose of understanding zoonosis dissemination in urban and rural environments. This type of research has great epidemiological value, because these animals are thoroughly diffused and share the same habitat as humans (12), and in many situations are considered family members.

Living in the same habitat, dogs and humans are equally exposed to sources of common environmental infections. In spite of the different hygiene habits among diverse human populations, canine toxoplasmosis can be an important epidemic indicator of the toxoplasmosis risk for humans (17). Thus, dogs could be considered animal sentries for this illness.

Several geographically distinct works in the literature present toxoplasmosis prevalence results varying between 20 and $80 \%$, employing different methodologies, in canine population. Table 1 summarizes the results obtained by several researchers, describing place, number of examined samples and method used.

Although $T$. gondii life cycle has been elucidated for more than three decades, little is known about the epidemiological importance of horizontal transmission. It is probable that the main transmission pathways vary among human populations, due to the differences in cultural and alimentary habits (24).

The multiple mechanisms of toxoplasmosis transmission make it one of the most predominant and propagated parasitic zoonoses on the planet (16). It is estimated that approximately one third of the worldwide human population has been exposed to T. gondii (13). In several studies carried out in the USA, Europe and Latin America, the seroprevalence varied in adults from 15 to $85 \%$, with the highest prevalence being found in humid tropical areas (9). 
Table 1. Anti-T. gondii antibody seroprevalence observed in dogs from different regions of the country (Brazil - 2002 to 2006)

\begin{tabular}{|c|c|c|c|c|}
\hline $\begin{array}{l}\text { Brazilian } \\
\text { Region }\end{array}$ & $\begin{array}{l}\text { Positive } \\
\text { results } \\
\text { (from total } \\
\text { samples) }\end{array}$ & $\begin{array}{c}\text { Seroprevalence } \\
(\%)\end{array}$ & Method & Reference \\
\hline Botucatu (SP) & $258 / 780$ & $33.10 \%$ & $\mathrm{IFAT}^{3}$ & $\begin{array}{l}\text { Langoni et al. } \\
\text { (14) }\end{array}$ \\
\hline Botucatu (SP) & $26 / 80$ & $32.50 \%$ & IFAT & Brito et al. (5) \\
\hline $\begin{array}{l}\text { Campina Grande } \\
\text { (PB) }\end{array}$ & $129 / 286$ & $45.10 \%$ & IFAT & $\begin{array}{l}\text { Azevedo et } \\
\text { al. (3) }\end{array}$ \\
\hline $\begin{array}{l}\text { Capão do Leão } \\
\text { (RS) }\end{array}$ & $10 / 50$ & $20 \%$ & $\mathrm{HIA}^{4}$ & $\begin{array}{l}\text { Cademartori } \\
\text { et al. (6) }\end{array}$ \\
\hline Monte Negro (RO) & $120 / 157$ & $76.40 \%$ & IFAT & $\begin{array}{l}\text { Cañón- } \\
\text { Franco et al. } \\
\text { (8) }\end{array}$ \\
\hline Salvador (BA) & $143 / 225$ & $63.55 \%$ & IFAT & $\begin{array}{l}\text { Barbosa et } \\
\text { al. (4) }\end{array}$ \\
\hline São Paulo (SP) ${ }^{1}$ & $24 / 29$ & $82.80 \%$ & IFAT & $\begin{array}{l}\text { Ortolani et al. } \\
\text { (19) }\end{array}$ \\
\hline São Paulo (SP) ${ }^{2}$ & $35 / 61$ & $57,40 \%$ & IFAT & $\begin{array}{l}\text { Ortolani et al. } \\
\text { (19) }\end{array}$ \\
\hline São Paulo (SP) & 219/1110 & $19.70 \%$ & MAT $^{5}$ & $\begin{array}{l}\text { Souza et al. } \\
(22)\end{array}$ \\
\hline São Paulo (SP) & $101 / 200$ & $50.50 \%$ & ELISA $^{6}$ & $\begin{array}{l}\text { Meireles et } \\
\text { al. (17) }\end{array}$ \\
\hline Ubatuba (SP) & $52 / 204$ & $25.49 \%$ & IFAT & $\begin{array}{l}\text { Silva et al. } \\
(21)\end{array}$ \\
\hline Uberlândia (MG) & $59 / 163$ & $36 \%$ & IFAT & $\begin{array}{l}\text { Mineo et al. } \\
(18)\end{array}$ \\
\hline
\end{tabular}

1: Krucutu indian settlement; 2: Morro da Saudade indian settlement; 3: indirect fluorescent antibody reaction; 4: hemagglutination-inhibition assay; 5: modified agglutination test; 6: enzyme-linked immunosorbent assay. 
The socioeconomic impact of toxoplasmosis is enormous, especially the high costs of treatment in children that have developed mental retardation and blindness due to this disease (20). In addition to these problems, this condition still causes miscarriages and serious sequelae generated by transplacentary infection.

Public health organizations, specifically the World Health Organization (WHO), have been encouraging the careful study of $T$. gondii aiming to produce accurate epidemic data on this parasite as a zoonotic agent. Such information is essential to reveal the importance of several infection sources for humans, in order to control the disease and to avoid harming life quality. Despite this fact, few countries are regularly monitoring toxoplasmosis in humans, and even less so in animals (24).

\section{MATERIAL AND METHODS}

\section{Epidemiological Survey}

The community from the neighborhood Jardim Santa Elisa, on the periphery of the urban territorial zone of Botucatu city, Sao Paulo State, Brazil, presents some transitory rural characteristics and can be considered as a poor district. The region is intercepted by three avenues (avenue 1, 2 and 3) and six streets (streets 1, 2, 3, 4, 5 and 6) while only avenue 2 is paved with asphalt, and the others are unpaved. According to the 2002 census, Jardim Santa Elisa district presents 228 residential buildings, none of which has access to residential pavement or adequate basic sanitation. The sewerage system covers only $46.1 \%$ of the homes; the others use cesspool and concrete cesspit (84.27\%), open sky sewers $(13.48 \%)$ or discard the sewer in stream water $(2.25 \%)$. The water supplied to the district is treated. The breeding of animals is intense, favoring promiscuous contact among them, because many are free in the streets or in improvised pastures.

Residential visits were accomplished during July of 2006. A questionnaire for epidemiological evaluation of the residents was applied and blood samples were collected from 100 dogs (48 males and 52 females), including 37 young animals ( 0 to 5 years old) and 63 senior animals (above 5 years old). According to the municipal government, there are approximately 250 dogs in the district, in agreement with the data referring to the animals vaccinated in 2005. This district has been monitored for some years by the Zoonosis Laboratory of the São Paulo State University with extension works for health education, but no previous study accomplished seroepidemiological evaluation of the district's animals for toxoplasmosis. 
The food supplied to the animals was divided in three categories: exclusively commercial (several available brands on the market); homemade food (surpluses of human food with varied composition, predominantly rice and sometimes meat); and processed and homemade food.

The animals' access to the street is free, without the owners' surveillance, due to the precarious conditions of housing infrastructures that don't possess physical barriers such as walls and gates that would impede the free movement of these animals. Thereby, allowing the constant contact between dogs and cats in the same environment.

The owners signed a consent form, clarifying the study objectives for them. The project was approved by the Ethics Committee for Animal Research of the School of Veterinary Medicine and Animal Husbandry, UNESP, protocol n. 145/2006-CEEA, following the Ethical Principles in Animal Experimentation. The risk factors evaluated were linked to canine feeding habits, street access, residential location and presence of rodents and felines.

\section{Blood Sample Collection}

Blood samples between 2 to $5 \mathrm{~mL}$ were taken from each animal by venous puncture (jugular or cephalic), with disposable $5 \mathrm{~mL}$ syringe and $30 \times 7 \mathrm{~mm}$ needle. The blood was transferred immediately to a $15 \mathrm{~mL}$ tube, without anticoagulant. In the laboratory of the Center for Zoonosis Research, NUPEZO, of the Department of Veterinary Hygiene and Public Health, UNESP, the samples were centrifuged at 3,000 rpm for 10 minutes, and then the serum was removed and transferred to $1,5 \mathrm{~mL}$ polystyrene tubes, identified and stored at $-20^{\circ} \mathrm{C}$, until the analysis.

\section{Indirect Fluorescent Antibody (IFA) Test}

IFA test was employed to detect anti- $T$. gondii antibodies, according to the standard technique described by Camargo (7).

The serum samples were diluted 1:16, 1:64, 1:256, 1:1,024, 1:4,096 in flat-bottom microplates and screened by IFA, for the detection of IgG antibodies. Conjugated anti-IgG was employed for the species studied. Peritoneal exudates of mice (Mus musculus), infected with Toxoplasma gondii tachyzoites of the RH strain, were used as antigen. Positive and negative control sera (previously known) were included on each plate. Readings were carried out in a fluorescent Zeiss SH 250 microscope, 
considering the condition in which the serum reacting at dilutions equal or higher than 1:16 as positive, when impregnated tachyzoite antigen showed total peripheral fluorescence. Absence of fluorescence, or its presence only in the parasite extremities (polar fluorescence), was considered a negative reaction.

\section{Statistical Analysis}

The chi-square test was used to determine statistical association between seroprevalence for toxoplasmosis in dogs and the risk factors evaluated by the questionnaire, with statistical significance of $95 \%, p \leq 0.05(23)$.

\section{RESULTS}

Of the 100 samples, 56 dogs showed anti-T. gondii antibodies (IgG). Among the positive results, 32 presented a titer of 16 (57.14\%); in 19 of them the titer was 64 (33.93\%); followed by four showing 256 titer (7.14\%) and one of 1.024 titer $(1.79 \%)$ (Table 2).

Table 2. Anti-T. gondii IgG antibody titer distribution in canine serum samples of Jardim Santa Elisa, Botucatu city, Sao Paulo State, Brazil, 2006.

\begin{tabular}{llc}
\hline Antibody titer & Reactive dogs \\
(UI) & Number & Percentage (\%) \\
\hline 16 & 32 & 57.14 \\
64 & 19 & 33.93 \\
256 & 4 & 7.14 \\
1024 & 1 & 1.79 \\
Total & $\mathbf{5 6}$ & $\mathbf{1 0 0}$ \\
\hline
\end{tabular}

Seropositivity for toxoplasmosis, according to the risk factors evaluated and to the occurrence probability $(p)$, is presented in Table 3.

In relation to street access, the percentage of seropositive dogs was statistically higher $(p=0.018$ ) than the one observed in the negative group for toxoplasmosis.

Of the seropositive dogs that feed on raw meat, the percentages observed in the infected group are greater $(p=0.027)$ than in the seronegative group. On the other hand, there was no association among dogs that receive only commercial ration, 
those fed exclusively homemade food and the ones fed both type, with $p=0.658, p=$ 0.107 and $p=0.207$, respectively.

Concerning young animals, the proportion that reacted was statistically less $(p=$ 0.020) than the non-reactive group. Regarding contact with cats, there was no statistically significant difference between dogs that reacted or not to toxoplasmosis $(p=0.207)$.

The risk evaluation in relation to the habits of hunting and coprophagy or xenosmophilia, in the present study, did not display significant association, with $p=$ 0.691 and $p=0.184$.

When verifying the percentage of seropositive and sinantropic dogs, an association was found since the number of reactive dogs was statistically greater $(p=0.015)$ than non-reactive ones.

No significant association was found for infection with regard to location in the neighborhood, specifically, among avenues 1, 2, 3 and the other locations; $p=0.797$, $p=0.935, p=0.262$ and $p=0.443$, respectively. 
L. G. Camossi et al. ENVIRONMENTAL RISK FACTORS FOR CANINE TOXOPLASMOSIS IN A DEPRIVED DISTRICT OF BOTUCATU, SP, BRAZIL. J. Venom. Anim. Toxins incl. Trop. Dis., 2008, 14, 3, p. 458

Table 3. Distribution of dogs that presented anti-T. gondii IgG antibodies, accordingly to epidemiological inquiry carried out in Jardim Santa Elisa, Botucatu city, 2006

\begin{tabular}{|c|c|c|c|c|}
\hline Variables & $\begin{array}{c}\text { Reactive } \\
\text { dogs } \\
\text { (number) }\end{array}$ & $\begin{array}{c}\text { Non-reactive } \\
\text { dogs (number) }\end{array}$ & $\begin{array}{c}\text { Total } \\
\text { (number) }\end{array}$ & $\mathbf{P}$ \\
\hline \multicolumn{5}{|l|}{ Access to street } \\
\hline Yes & 45 & 27 & 72 & 0.018 \\
\hline No & 11 & 17 & 28 & \\
\hline \multicolumn{5}{|l|}{ Age (years) } \\
\hline $0-5$ & 14 & 23 & 37 & 0.020 \\
\hline$>5$ & 42 & 21 & 63 & \\
\hline \multicolumn{5}{|l|}{ Raw meat ingestion } \\
\hline Yes & 21 & 9 & 30 & 0.027 \\
\hline No & 35 & 35 & 70 & \\
\hline Exclusive feeding of commercial dog food & 18 & 16 & 34 & 0.658 \\
\hline Feeding of homemade food & 25 & 12 & 37 & 0.107 \\
\hline \multicolumn{5}{|l|}{ Feeding of commercial and homemade } \\
\hline food & 13 & 16 & 29 & 0.218 \\
\hline \multicolumn{5}{|l|}{ Frequent contact with felines } \\
\hline Yes & 15 & 17 & 32 & 0.207 \\
\hline No & 41 & 27 & 68 & \\
\hline \multicolumn{5}{|l|}{ Hunting habit } \\
\hline Yes & 17 & 15 & 32 & 0.691 \\
\hline No & 39 & 29 & 68 & \\
\hline \multicolumn{5}{|l|}{ Coprophagia/xenosmophilia behavior } \\
\hline Yes & 12 & 5 & 17 & 0.184 \\
\hline No & 44 & 39 & 83 & \\
\hline \multicolumn{5}{|l|}{ Presence of synanthropic animals } \\
\hline Yes & 42 & 24 & 66 & 0.015 \\
\hline No & 14 & 20 & 34 & \\
\hline \multicolumn{5}{|l|}{ District distribution } \\
\hline Avenue 1 & 14 & 12 & 26 & 0.797 \\
\hline Avenue 2 & 25 & 20 & 45 & 0.935 \\
\hline Avenue 3 & 11 & 5 & 16 & 0.262 \\
\hline Streets & 6 & 7 & 13 & 0.443 \\
\hline
\end{tabular}

Statistic: chi-square test. 


\section{DISCUSSION}

The literature consulted showed results varying between $20.0 \%$ (6) and $82.80 \%$ (19) for canine toxoplasmosis seropositivity. The $56.0 \%$ prevalence of toxoplasmic infection in the dog population from the Jardim Santa Elisa district may be considered a high result. This data does not necessarily signify that animals have toxoplasmosis. It only denotes that these dogs had contact with the pathogenic agent, and thereby the acquired infection. Since these animals share common infection sources with their owners or other residents of the neighborhood, they constitute a risk factor for the local human population (12).

The results from the current study are similar to the ones obtained by Ortolani et al. (19), who found $57.40 \%$ positivity in dogs from the indigenous village Morro da Saudade, in São Paulo city. They are also comparable to the outcomes obtained by Barbosa et al. (4) and Meirelles et al. (17) that, respectively, observed $63.55 \%$ and $50.50 \%$ positivity; rates lower, however, than the results achieved by Ortolani et al. (19) in their study on dogs of another indigenous village, Krucutu, where they encountered $82.80 \%$ of dogs with anti-T.gondii antibodies.

On the other hand, the levels found in the present study are higher than follow-ups performed by Mineo et al. (18), Brito et al. (5), Silva et al. (21), Souza et al. (22), Cademartori et al. (6), Azevedo et al. (3) and Langoni et al. (14), who verified, respectively, 3.0\%, 32.5\%, 25.49\%, 19.70\%, 20.0\%, 45.10\% and 33.10\%.

Conclusions from Cañón-Franco et al. (8) and Ortolani et al. (19) presented numbers above the $56.9 \%$ positivity verified in the Jardim Santa Elisa district; these two groups found respective positivities of $76.40 \%$ and $82.80 \%$.

The differences among several research results should be appraised in terms of numbers of samples evaluated and the methodology used because these factors can interfere in the antibody titer obtained, and not only in toxoplasmosis cases. Another aspect to be highlighted is the inter-technician variation, besides characteristics of reagents, antigens and conjugates that are from different laboratories.

Apart from these factors, results diverge among the same researchers when animal samples come from different places. This fact confirms the importance of the environment over agent maintenance and, consequently, over toxoplasmosis transmission to animals, including humans (4).

In developing countries, namely Brazil, the toxoplasmosis incidence is high and its transmission is related to hygiene habits, poor sanitation, feline presence and 
climatic factors. These aspects contribute to the process of parasite development process and transmission. Its prevalence varies among areas and depends on the existence of risk factors, justifying the results found in several studies (8).

The titer most frequently observed in this study was 16 (57.14\%), which agrees with the one observed by Langoni et al. (14) in the same district, who employed the same serologic test. Findings like the anti-T. gondii antibody titer 16 in a sample can simply confirm that the animal had contact with the agent. A second serology, screening only IgG antibodies, after a couple of weeks is necessary to differentiate a chronic infection from an active current infection.

The variable street access exerted some influence on the results obtained in the current study. This agrees with several authors, such as Ali et al. (1) that found in Trinidad and Tobago a prevalence of $51 \%$ for toxoplasmosis in dogs that had access to street and $14.7 \%$ in animals maintained strictly in domestic environment, a difference that was statistically significant $(p=0.004)$. A similar result was observed in Monte Negro, Rondônia, where Cañón-Franco et al. (8) encountered positive association between dogs that had unrestricted street access (84.9\% prevalence) and the ones kept on the domestic property $(58.8 \%)(p \leq 0.001)$.

It is suggested that dogs that can move freely through neighborhood are more susceptible to infection by $T$. gondii oocysts from water and food. In addition, street access can favor hunting chances, inherent to the behavior of a carnivorous animal (5).

A positive correlation between raw meat supply and seropositivity for toxoplasmosis was found in dogs. Thus, raw meat is considered an important source of transmission to humans and other animals. Garcia et al. (12) also demonstrated a positive correlation between the antibody titer distribution ratio for the human and canine species, confirming that the man-dog relationship was epidemically relevant, possibly due to the same transmission pathways, i.e., raw food.

No substantial differences were detected for seropositivity distribution among animals fed exclusively commercial food, only homemade food or both together. This conclusion is in agreement with Ali et al. (1), who despite finding a higher prevalence in dogs that received homemade food, did not conclude that this difference was significant when compared to the percentage of animals that were fed commercial ration or both types jointly $(p=0.05)$. Cañón-Franco et al. (8) confirmed this, when they compared commercial diet with a homemade one $(p=0.086)$. 
Our current results on the risk factor due to frequent contact with cats were similar to those obtained by Ali et al. (1), who also did not observe statistical differences. These outcomes suggest that environmental exposure to T. gondii can be epidemiologically more important than direct contact with cats. In this case, cats assume an important role not by direct contact, but by oocyst elimination and environmental contamination, thus posing greater risk for human and others animal populations. A study by Azevedo et al. (3) revealed important association between seropositivity and domestic presence of cats.

The percentage of young animals that reacted was statistically lower $(p=0.020)$ than the one observed in the non-reactive group, reinforcing the results found by Ali et al. (1), Cañón-Franco et al. (8) and Garcia et al. (12), who all corroborated on the higher probability of adult animals having had previous contact with the parasite.

Contrary to what was expected, canine hunting habits did not increase toxoplasmosis seroprevalence; which can be explained, partially, by the fact that the present study did not evaluate if the dogs ate the hunted animals. Besides, since these animals have free access to the street, their owners could not say wether the dogs were hunting or not.

Positive association was observed between seropositivity and presence of sinantropic animals, contrary to Azevedo et al. (3) who did not find significant disparity between the presence of rodents and other preys and the presence of titers for toxoplasmosis in dogs. 


\section{ACKNOWLEDGEMENTS}

We would like to thank Haroldo Greca Junior for intellectual assistance.

\section{REFERENCES}

1 ALI CN., HARRIS JA., WATKINS JD., ADESIYUN, AA. Seroepidemiology of Toxoplasma gondii in dogs in Trinidad and Tobago. Vet. Parasitol., 2003, 113, 17987.

2 ARAÚJO WN., SILVA AV., LANGONI H. Toxoplasmose: uma zoonose - realidade e riscos. Cães e Gatos, 1998, 79, 20-7.

3 AZEVEDO SS., BATISTA CSA., VASCONCELLOS AS., AGUIAR DM., RAGOSO AMA., RODRIGUES AAR., ALVES CJ., GENNARI SM. Seroepidemiology of Toxoplasma gondii and Neospora caninum in dogs from the state of Paraíba, northeast region of Brazil. Res. Vet. Sci., 2005, 79, 51-6.

4 BARBOSA MVF., GUIMARÃES JE., ALMEIDA MAO., GONDIM LFP., REGIS GB. Freqüência de anticorpos IgG anti-Toxoplasma gondii em soros de cães errantes da cidade de Salvador-Bahia, Brasil. Braz. J. Vet. Res. Anim. Sci., 2003, 40, 457-65.

5 BRITO AF., SOUZA LC., SILVA AV., LANGONI H. Epidemiological and serological aspects in canine toxoplasmosis in animals with nervous symptoms. Mem. Inst. Oswaldo Cruz, 2002, 97, 31-5.

6 CADEMARTORI BG., RECUERO RC., JORGE S., DIAS DG., FERNANDES CPH., RECUERO ALC., PILTCHER MG., BROD CS. Detecção de anticorpos IgG antiToxoplasma gondii em cães do bairro Jardim América, Município do Capão do Leão, RS. In: Congresso de Iniciação Científica, 14. Pelotas: Universidade Federal de Pelotas, 2005. 
L. G. Camossi et al. ENVIRONMENTAL RISK FACTORS FOR CANINE TOXOPLASMOSIS IN A DEPRIVED DISTRICT OF BOTUCATU, SP, BRAZIL. J. Venom. Anim. Toxins incl. Trop. Dis., 2008, 14, 3, p. 463

7 CAMARGO ME. Introdução às técnicas de imunofluorescência. Rev. Bras. Patol. Clin., 1974, 10, 143-69.

8 CAÑÓN-FRANCO WA., BERGAMASCHI DP., LABRUNA MB., CAMARGO LM., SILVA JC., PINTER A., GENNARI SM. Occurrence of anti-Toxoplasma gondii antibodies in dogs in the urban area of Monte Negro, Rondônia, Brazil. Vet. Res. Commun., 2004, 28, 113-8.

9 DUBEY JP. Strategies to reduce transmission of Toxoplasma gondii to animals and humans. Vet. Parasitol., 1996, 64, 65-70.

10 DUBEY JP., LINDSAY DS., SPEER CA. Structures of Toxoplasma gondii tachyzoites, bradyzoites, and sporozoites and biology and development of tissue cysts. Clin. Microbiol. Rev., 1998, 11, 267-99.

11 FORTES E. Parasitologia Veterinária. 4.ed. São Paulo: Ícone Editora Itda., 2004. $607 p$.

12 GARCIA JL., NAVARRO IT., OGAWA L., OLIVEIRA RC., KOBILKA E. Soroprevalência, epidemiologia e avaliação ocular da toxoplasmose humana na zona rural de Jaguapitã (Paraná), Brasil. Rev. Panam. Salud Publica, 1999, 6, 15763.

13 HILL D., DUBEY, JP. Toxoplasma gondii: transmission, diagnosis and prevention. Clin. Microbiol. Infect., 2002, 8, 634-40.

14 LANGONI H., MODOLO JR., PEZERICO SB., SILVA RC., CASTRO APB., SILVA AV., PADOVANI CR. Serological profile of anti-Toxoplasma gondii antibodies in apparently healthy dogs of the city of Botucatu, São Paulo state, Brazil. J. Venom. Anim. Toxins incl. Trop. Dis., 2006, 12, 142-8.

15 LINDSAY DS., DUBEY JP., BUTLER JM., BLAGBURN, BL. Mechanical transmission of Toxoplasma gondii oocysts by dogs. Vet. Parasitol., 1997, 73,27-33. 
16 MACPHERSON CN. Human behaviour and the epidemiology of parasitic zoonoses. Int. J. Parasitol., 2005, 35, 1319-31.

17 MEIRELES LR., GALISTEO JR AJ., POMPEU E., ANDRADE JR HF. Toxoplasma gondii spreading in a urban área evaluated by seroprevalence in free-living cats and dogs. Trop. Med. Int. Health, 2004, 9, 876-81.

18 MINEO TWP., SILVA DAO., NÄSLUNA K., BJÖRKMAN C., UGGLA A., MINEO JR. Toxoplasma gondii and Neospora caninum serological status of different canine populations from Uberlândia, Minas Gerais. Arq. Bras. Med. Vet. Zootec., 2004, 56, 414-7.

19 ORTOLANI ES., GENNARI SM., PINHEIRO SR., RODRIGUES AAR., CHIEBAO DP., SOARES RM. Prevalência de anticorpos anti-Toxoplasma gondii em populações animais das aldeias indígenas Krucutu e Morro da Saudade, no município de São Paulo, Brasil. Vet. Zootec., 2005, 12, 25-8.

20 ROBERTS T., MURRELL KD., MARKS S. Economic losses caused by foodborne parasitic diseases. Parasitol. Today, 1994, 10, 419-23.

21 SILVA RC., ROLIM RG., TANAKA EM., LANGONI H., LOPES ALS., ROCHA FA., CAVALHEIRO JS., MEDEIROS MIM., BORGES SR., BERETTA TC., LIMA VY., AOKI VL., SILVA AV., SOUZA LC. Avaliação soroepidemiológica da toxoplasmose, leptospirose e leishmaniose canina no município de Ubatuba, SP. Arq. Inst. Biol., 2003, 70, 424-8.

22 SOUZA SLP., GENNARI SM., YAI LEO., D'AURIA SRN., CARDOSO SMS., GUIMARÃES JR JS., DUBEY JP. Occurrence of Toxoplasma gondii antibodies in sera from dogs of the urban and rural areas from Brazil. Rev. Bras. Parasitol. Vet., $2003,12,1-3$ 
L. G. Camossi et al. ENVIRONMENTAL RISK FACTORS FOR CANINE TOXOPLASMOSIS IN A DEPRIVED DISTRICT OF BOTUCATU, SP, BRAZIL. J. Venom. Anim. Toxins incl. Trop. Dis., 2008, 14, 3, p. 465

23 STREINER DL, NORMAN GR. Bioestatistic: the bare essentials. St. Louis: Mosby-Year Book, 1994. 260p.

24 TENTER AM., HECKEROTH AR., WEISS LM. Toxoplasma gondii: from animals to humans. Int. J. Parasitol., 2000, 30, 1217-58. 